\title{
Transcriptional regulation of androgen receptor gene expression in Sertoli cells and other cell types
}

\author{
Leen J. Blok ${ }^{\text {a }}$, Axel P.N. Themmen ${ }^{\text {a }}$, Antoine H.F.M. Peters ${ }^{\text {a }}$, Jan Trapman ${ }^{\text {b }}$, \\ Willy M. Baarends a, Jos W. Hoogerbrugge a and J. Anton Grootegoed 'a \\ ${ }^{a}$ Department of Endocrinology and Reproduction and ${ }^{b}$ Department of Pathology, Medical Faculty, Erasmus University Rotterdam, \\ 3000 DR Rotterdam, Netherlands
}

(Received 22 April 1992; accepted 3 July 1992)

Key words: Androgen receptor; Follicle-stimulating hormone; Dibutyryl-cylic AMP; Androgen; Transcription; Sertoli cell; Peritubular myoid cell; LNCaP cell

\section{Summary}

Regulation of androgen receptor (AR) mRNA expression was studied in Sertoli cells and peritubular myoid cells isolated from immature rat testis, and in the lymph node carcinoma cell line derived from a human prostate (LNCaP). Addition of dibutyryl-cyclic AMP (dbcAMP) to Sertoli cell cultures resulted in a rapid transient decrease in AR mRNA expression $(5 \mathrm{~h})$, which was followed by a gradual increase in AR mRNA expression (24-72 h). This effect of dbcAMP mimicked follicle-stimulating hormone (FSH) action. In peritubular myoid cells, there was only a moderate but prolonged decrease during incubation in the presence of dbcAMP, and in LNCaP cells no effect of dbcAMP on AR mRNA expression was observed.

When Sertoli cells or peritubular myoid cells were cultured in the presence of androgens, AR mRNA expression in these cell types did not change. This is in contrast to LNCaP cells, that showed a marked reduction of AR mRNA expression during androgen treatment.

In the present experiments, transcriptional regulation of AR gene expression in Sertoli cells and LNCaP cells was also examined. Freshly isolated Sertoli cell clusters were transfected with a series of luciferase reporter gene constructs, driven by the AR promoter. It was found that addition of dbcAMP to the transfected Sertoli cells resulted in a small but consistent increase in reporter gene expression (which was interpreted as resulting from AR promoter activity); a construct that only contained the AR 5' untranslated region of the cDNA sequence did not show such a regulation. The same constructs, transfected into LNCaP cells, did not show any transcriptional down-regulation when the synthetic androgen R1881 was added to the cell cultures. A nuclear transcription elongation experiment (run-on), however, demonstrated that androgen-induced AR mRNA down-regulation in LNCaP cells resulted from an inhibition of $A R$ gene transcription.

Correspondence to: Leen J. Blok, Department of Endocrinology and Reproduction, Medical Faculty, Erasmus University Rotterdam, P.O. Box 1738, 3000 DR Rotterdam, Netherlands. Tel. (31) 10-4087345; Fax (31) 10-4366832. 
The present results indicate that in Sertoli cells and LNCaP cells, hormonal effects on AR gene transcription play a role in regulation of AR expression. Howcver, AR gene transcription in these cells is differentially regulated.

\section{Introduction}

In the mammalian testis, follicle-stimulating hormone (FSH) and testosterone exert co-operative actions in the initiation and maintenance of spermatogenesis (Clermont and Harvey, 1967; Steinberger, 1971; Hansson et al., 1975; Fritz, 1978; Marshall and Nieschlag, 1987; Russell et al., 1987; Bartlett et al., 1989; Matsumoto and Bremner, 1989). In general, the quality and quantity of spermatogenesis are used as a parameter to evaluate the relative importance of $\mathrm{FSH}$ and testosterone. Using cultured Sertoli cells, several specific or common actions of FSH and testosterone, in particular on protein synthesis, have been observed (Cheng et al., 1986). Recently, co-operation between FSH and testosterone has becn observed on the level of androgen receptor (AR) regulation. In cultured immature rat Sertoli cells, long-term ( $72 \mathrm{~h}$ ) addition of FSH to the culture medium resulted in an increased expression of both AR mRNA and protein (Verhoeven and Cailleau, 1988; Blok et al., 1989, 1992b; Sanborn et al., 1991). Testosterone addition to the cultured cells did not markedly affect AR mRNA expression, but resulted in increased stability of AR protein (Blok et al., 1989, 1992b). The effects of FSH and testosterone on the expression of AR protein appeared to be additive (Blok et al., 1989, 1992b).

Sertoli cells and peritubular myoid cells are an important source of AR protein in the rat testis (Takeda et al., 1989; Sar et al., 1990). To obtain more information on regulation of AR mRNA expression in these testicular cell types, Sertoli cells and peritubular myoid cells were isolated from immature rats and cultured in the presence or absence of FSH, dbcAMP or testosterone. LNCaP cells (cell line derived from a lymph node metastasis from a human prostate carcinoma, Horoszewicz et al., 1983) were included in this analysis, because androgen-induced down-regu- lation of AR mRNA expression is a more general phenomenon which also occurs in these cells (Quarmby et al., 1990; Tilley et al., 1990; Trapman et al., 1990; Krongrad et al., 1991). Northern blotting was performed to analyze the regulation of AR mRNA expression in the different cell types.

Structural analysis of the rat and human AR promoter region (Baarends et al., 1990; Faber et al., 1991) did not reveal the presence of consensus sequences that could act as cyclic AMP response elements (CRE) through which FSH could regulate AR gene transcription. Several glucocorticoid response element (GRE) half-sites were found in the AR promoter, but it remains to be established whether these GRE half-sites are functional in the regulation of AR gene transcription. To study whether or not regulation of AR mRNA expression by FSH (Sertoli cells) and testosterone ( $\mathrm{LNCaP}$ cells) is caused by changes in $\mathrm{AR}$ gene transcription, rather than through an effect on mRNA stability, reporter constructs were made that contained up to $7 \mathrm{~kb} 5^{\prime}$ upstream sequences of the AR gene start site. These constructs were transfected into cultured immaturc Sertoli cells and LNCaP cells, to test regulation of their transcription. Regulation of $\mathrm{AR}$ gene transcription by FSH or testosterone was also studied using a nuclear transcription elongation (nuclear run-on) assay.

\section{Materials and methods}

Cell culture for $R N A$ isolation and nuclear run-on

Sertoli cells were isolated from 15-day-old rats, and cultured as described by Themmen et al. (1991). Peritubular myoid cells were obtained from the same testes as the Sertoli cells, as follows. The testes were decapsulated and incubated in $20 \mathrm{ml}$ phosphate-buffered saline (PBS) containing $5 \mu \mathrm{g} / \mathrm{ml} \mathrm{DNase} \mathrm{(DN-25;} \mathrm{Sigma,} \mathrm{St.} \mathrm{Louis,}$ MO, USA), $1 \mathrm{mg} / \mathrm{ml}$ collagenase A (Boehringer 
Mannheim, Mannheim, Germany), $1 \mathrm{mg} / \mathrm{ml}$ hyaluronidase (I-S; Sigma), and $1 \mathrm{mg} / \mathrm{ml}$ trypsin (TRL, Cooper Biomedical, Freehold, NJ, USA), for $25 \mathrm{~min}$ at $37^{\circ} \mathrm{C}$ in a $100 \mathrm{ml}$ Erlenmeyer flask, in a shaking waterbath (120 cycles/min). During this treatment, interstitial and peritubular myoid cells became dissociated from the seminiferous tubule fragments; these fragments were removed by sedimentation at unit gravity for $2 \mathrm{~min}$ in 50 ml PBS containing $5 \mu \mathrm{g} / \mathrm{ml}$ DNase. The supernatant was filtered through a $60 \mu \mathrm{m}$ nylon filter, and centrifuged for $2 \mathrm{~min}$ at $7 \times \mathrm{g}$. The cells in the supernatant were precipitated by centrifugation at $30 \times g$ for $2 \mathrm{~min}$. The interstitial and peritubular myoid cells were seeded at a density of approximately $3 \times 10^{4}$ cells per $\mathrm{cm}^{2}$, in Eagle's minimum essential medium (Gibco BRL, Middlesex, UK), supplemented with antibiotics and non-essential amino acids (MEM; Oonk et al., 1985) and containing $10 \%$ foetal calf serum (FCS). At the beginning of the culture period, the cell preparation contained approximately $50 \%$ peritubular myoid cells, as determined by alkaline phosphatase staining (Palombi et al., 1989). The cultures were grown to near confluency in 3 days. The purity at that time was higher than $95 \%$. All experiments with peritubular myoid cells were performed in MEM containing $0.1 \%$ bovine serum albumin (BSA; fraction V, Sigma). The cells were cultured in the presence or absence of hormones as indicated in the Results section.

LNCaP cells (passages 45-50) were cultured in RPMI, containing antibiotics (see above) and $7.5 \%$ FCS, to $50 \%$ confluency. To study regulation of AR mRNA expression (Northern blotting and nuclear run-on analyses), the cells were cultured in RPMI containing 7.5\% Dextran-coated charcoal-treated FCS (DCC-FCS), supplemented with hormones as indicated in the Results section.

Total RNA was isolated from Sertoli, peritubular myoid and LNCaP cells as described by Blok et al. (1992a). The nuclear run-on assays were carried out in duplicate as described by Blok et al. (1992b). In this assay, the transcription elongation was allowed to continue for $30 \mathrm{~min}$ in the isolated nuclei, in the presence of labelled mRNA precursors. The mRNAs were hybridized to the complete human AR cDNA (Trapman et al., 1988; Faber et al., 1991; Jenster et al., 1991), and autoradiographed. The films were scanned using a video densitometer (Bio-Rad, model 620).

\section{Isolation and transfection of Sertoli cell clusters}

Tubule fragments obtained from testes from 15-day-old rats in the procedure for isolation of peritubular myoid cells (see above), were the source of Sertoli cell clusters that werc used for transfection. The tubule fragments, cell clusters consisting of Sertoli cells with a few adherent germ cells (mainly spermatocytes), were allowed to attach in plastic Petri dishes $(60 \times 15 \mathrm{~mm}$, Nunclon, Roskilde, Denmark), at a density of approximately $3 \times 10^{5}$ cells $/ \mathrm{cm}^{2}$, for $4 \mathrm{~h}$ before transfection. The Sertoli cell clusters were cultured in $\mathrm{MEM}$, at $37^{\circ} \mathrm{C}$ under an atmosphere of $5 \% \mathrm{CO}_{2}$ in air, in the presence of $5 \%$ DCC-FCS.

DNA precipitate was produced using the calcium phosphate method (Chen and Okayama, 1987). Per culture dish with $4 \mathrm{ml}$ medium, $250 \mu \mathrm{l}$ precipitate containing $5 \mu \mathrm{g}$ plasmid DNA construct was added, and kept on the cells for $15 \mathrm{~h}$. Subsequently, the cells were washed with PBS (without $\mathrm{Ca}^{2+}$ and $\mathrm{Mg}^{2+}$ ) before being subjected to a 1.5 min shock treatment with $15 \%(\mathrm{v} / \mathrm{v})$ glycerol in PBS (without $\mathrm{Ca}^{2+}$ and $\mathrm{Mg}^{2+}$ ). This was followed by two wash steps and addition of fresh medium (MEM supplemented with 5\% DCC-FCS). After a $6 \mathrm{~h}$ incubation period, the medium was again replaced by fresh medium supplemented with or without hormones. The incubations of the Sertoli cells with of without hormones were continued for $24 \mathrm{~h}$ because Blok et al. (1992b) have reported a significant increase in AR mRNA and protein expression after $24 \mathrm{~h}$ of culture in the presence of FSH. In a number of experiments, the pCH110 $\beta$-galactosidase expression plasmid (Pharmacia LKB Biotechnology, Uppsala, Sweden) was co-transfected as an internal control. Within one experiment, all incubations were terminated at the same time point (control and hormone-treated). The hormone treatment protocols are described in the Results section.

The cells were harvested in $0.5 \mathrm{ml}$ extraction buffer (100 mM Tris pH 7.8, $8 \mathrm{mM} \mathrm{MgCl}, 1 \mathrm{mM}$ dithiothreitol, $15 \%$ glycerol, $0.2 \%$ Triton X-100). For estimation of luciferase activity, a small test 
tube containing $40 \mu \mathrm{l}$ of this reaction mixture was placed in a luminometer (Pico-lite 6100; Packard, Downers Grove, IL, USA), and the reaction was initiated by injection of $10 \mu \mathrm{l}$ of $0.5 \mathrm{mM}$ luciferin (Sigma), $50 \mathrm{mM}$ ATP, pH 7. Light emission was measured during the first $15 \mathrm{~s}$ of the reaction (integral mode). The transfection experiments were repeated 4-5 times, using different cell isolates and plasmid preparations. The presented luciferase activities are from four different transfections in one representative experiment.

Alkaline phosphatase staining was used to evaluate contamination with peritubular myoid cells in the Sertoli cell clusters (Palombi et al.,

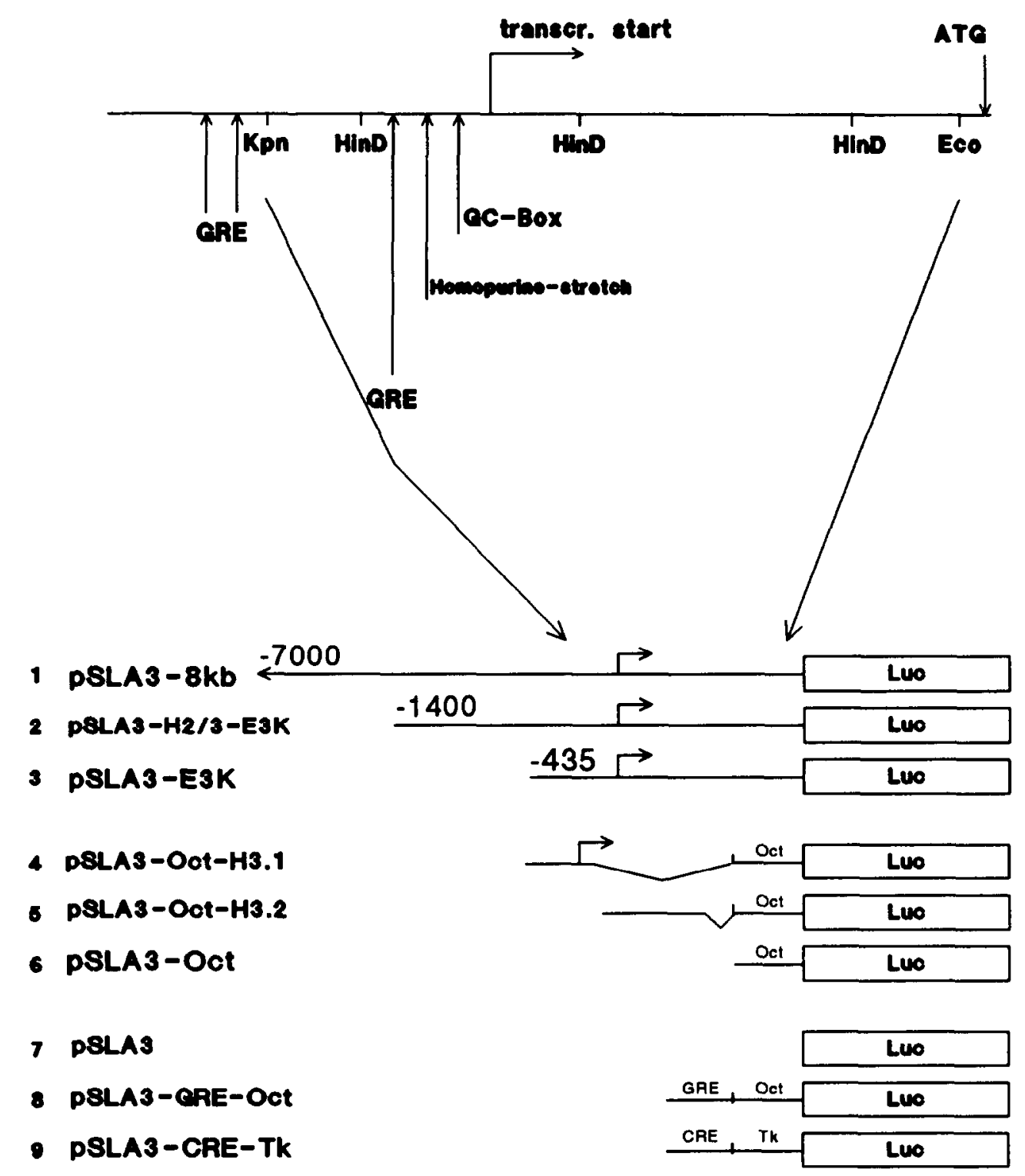

Fig. 1. AR gene promoter/reporter constructs. Constructs 1-4 contain regions of the AR gene promoter (Baarends et al., 1990). Construct 5 contains the $5^{\prime}$ untranslated region of the cDNA sequence from the AR gene, cloned in front of a minimal promoter (Oct-6 promoter). Constructs 6 and 7 are controls for the basal rate of luciferase gene transcription. Construct 7 is a positive control for AR-stimulated transcription, and construct 8 is a positive control for dbcAMP-stimulated transcription. 
1989). This contamination was below $3 \%$, and the contamination with spermatocytes was approximately $10 \%$ (at the end of the incubations).

\section{LNCaP cell transfection}

LNCaP cells were cultured in MEM containing 7.5\% DCC-FCS, and transfected as described for Sertoli cells. The transfected cells were stimulated for $24 \mathrm{~h}$ with hormones, as described in the Results section, and harvested to measure the luciferase activity. The transfection experiments were repeated 4-5 times. The presented luciferase activities are frome four different transfections in one representative experiment.

\section{Plasmids}

For construction of most plasmids, the pSLA3 vector was used (van Dijk et al., 1991) that is a derivative of pSuperCAT. Several restriction fragments derived from GrAR2 (Baarends et al., 1990) were subcloned into pSLA3, using standard methods (Sambrook et al., 1989). In a number of constructs, an octamer binding protein promoter (mouse Oct-6; kindly provided by Dr. D. Meijer, Rotterdam, Netherlands) was used as a minimal promoter.

The $p S L A 3-E 3 K$ promoter/reporter construct was generated as follows. A $1.5 \mathrm{~kb} \mathrm{KpnI/EcoRI}$ fragment derived from GrAR2, containing the AR promoter and $5^{\prime}$ untranslated region of the cDNA ( -435 to +966 ) (Fig. 1), was inserted in the KpnI and EcoRI sites of pGEM (pGEME3K). From this vector, a ClaI/EcoRI fragment was isolated and ligated into the ClaI/EcoRI sites of pSLA3. pSLA3-H2/3-E3K was constructed by cloning a HindIII/HindIII fragment, derived from GrAR2, into the HindIII site of a Bluescript vector (pBLUE-H2/3). A pBLUE$\mathrm{H} 2 / 3 \mathrm{ClaI} / \mathrm{KpnI}$ fragment $(1.3 \mathrm{~kb})$ was placed in front of the E3K fragment in pSLA3-E3K (in ClaI and KpnI sites). pSLA3-8kb was constructed by integration of a $6.5 \mathrm{~kb} \mathrm{BamHI} / \mathrm{KpnI}$ fragment, derived from GrAR2, into the BamHI and KpnI sites in front of the E3K fragment in pSLA3-E3K. pSLA3-CRE-tk was constructed by ligation of a BamHI/PvuII fragment (containing two CRE consensus sequences derived from the human fibronectin gene; kindly provided by Dr. R. Offringa) into the BamHI/SmaI sites of
pSLA3-tk (van Dijk et al., 1991). To obtain pSLA3-oct, a pGEM7 polylinker region was inserted in front of the tk promoter of the pSLA3-tk vector. A HindIII/XhoI fragment containing the Oct-6 minimal promoter was then cloned into the HindIII/XhoI sites of the polylinker region of the pSLA3-pl-tk vector (pSLA3-pl-oct-tk). Finally, the tk promoter was removed from pSLA3pl-oct-tk by using BgIII/XhoI (pSLA3-oct). $p S L A 3-$ oct-E3K was constructed by insertion of the KpnI/EcoRI fragment, derived from pSLA3$\mathrm{E} 3 \mathrm{k}$, into the SmaI site of the pSLA3-oct. pSLA3-oct-H3.1 and pSLA3-oct-H3.2 were constructed by cloning both HindIII fragments (H3.1 (= $411 \mathrm{bp}$, containing the AR promoter region) and $\mathrm{H} 3.2 \mathrm{C}=610 \mathrm{bp}$, containing a large portion of the AR 5' untranslated cDNA sequence)) separately into the HindIII site of pSL $\Lambda 3$-oct. PSLA3-oct-GRE was constructed by cloning a HindIII fragment from pG-29G-tkCAT (Schule et al., 1988), into the HindIII site of the pSLA3oct plasmid.

\section{Results}

\section{AR $m R N A$ expression}

When Sertoli cells were cultured in the presence of FSH or dbcAMP for $5 \mathrm{~h}$, a rapid but transient decrease in AR mRNA expression was observed (Fig. 2A). However, when FSH or dbcAMP was present for longer time periods ( $72 \mathrm{~h}$ ), AR mRNA expression became elevated to values above the control level (FSH gave a $2.4 \pm 0.2$-fold induction, and dbcAMP a $2.1 \pm 0.3$-fold induction; mean $\pm \mathrm{SD}$ of four experiments). Addition of the synthetic androgen R1881 to the cultures did not result in changes in AR mRNA expression. Actin mRNA expression was not significantly affected by the hormone treatments (Fig. 2B).

Peritubular myoid cells showed a small decrease in AR mRNA expression, $5 \mathrm{~h}$ and $72 \mathrm{~h}$ after addition of dbcAMP (30\% decrease; Fig. $3 A$ ). Such a decrease was also observed for the actin mRNA level (Fig. $3 B$ ), but not for GAPDH mRNA expression (Fig. 3C). Therefore, it was concluded that dbcAMP had a small inhibitory effect on the expression of both actin and AR mRNAs in cultured peritubular myoid cells. This 


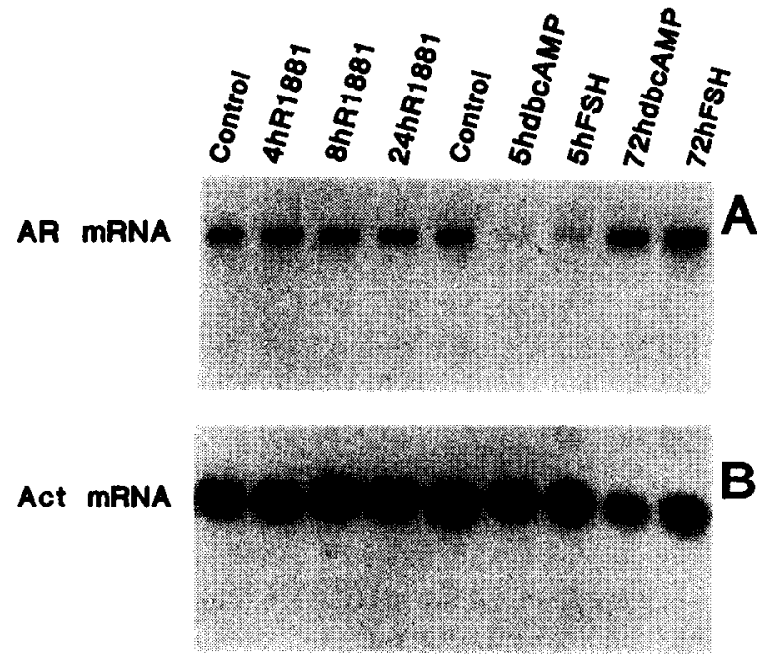

Fig. 2. Effect of FSH, dbcAMP and R1881 on AR mRNA expression in cultured Sertoli cells. Sertoli cells from 15-dayold rats were cultured in the presence of ovine FSH-S16 (500 $\mathrm{ng} / \mathrm{ml})$, dbcAMP $(0.5 \mathrm{mM})$ or R1881 $\left(10^{-8} \mathrm{M}\right)$ for different time periods. 4 hR1881, 8hR1881, 24hR1881 = cultured for 4 $\mathrm{h}, 8 \mathrm{~h}$ or $24 \mathrm{~h}$ in the presence of R1881; 5hdbcAMP, $72 \mathrm{hdbcAMP}=$ cultured for $5 \mathrm{~h}$, or $72 \mathrm{~h}$ in the presence of dbcAMP; $5 \mathrm{hFSH}, 72 \mathrm{hFSH}=$ cultured for $5 \mathrm{~h}$ or $72 \mathrm{~h}$ in the presence of FSH. For Northern analysis, $20 \mu \mathrm{g}$ of total RNA was applied per lane and analyzed using a human AR cDNA probe $(A)$; a hamster actin cDNA probe $(B)$ was used to verify whether equal amounts of mRNA were applied to each lane on the gel.

effect, however, was different from the transient decrease $(5 \mathrm{~h})$ and gradual increase $(72 \mathrm{~h})$ of AR mRNA expression in dbcAMP-treated Sertoli cells. Incubation of peritubular myoid cell preparations in the presence of FSH had no effect on AR mRNA expression, confirming that this cell preparation did not contain a substantial number of Sertoli cells. Addition of R1881 to the cultured peritubular myoid cells did not result in changes in the expression of AR mRNA or actin mRNA (Fig. $3 A$ and $3 B$ ).

In LNCaP cells, no short- or long-term regulation of AR mRNA expression by dbcAMP could be observed (Fig. 4A). Addition of R1881 to LNCaP cell cultures, however, did result in a marked reduction of the AR mRNA level (Fig. $4 A$ ). This contrasts with the absence of an effect of R1881 on AR mRNA expression in Sertoli and peritubular myoid cell cultures (Figs. $2 A$ and $3 A$ ). Actin mRNA expression remained unal- tered during the different hormonal treatments of LNCaP cells (Fig. 4B).

\section{Transfection of Sertoli cells}

Various methods were examined to try to transfect primary Sertoli cell cultures. Monolayers of Sertoli cells from immature rats, cultured for several days in the presence or absence of hormones, showed very little uptake and expression of various CAT reporter gene constructs. Higher construct uptake was observed using freshly isolated Sertoli cell clusters that were transfected shortly after isolation. Furthermore, the sensitivity of the assay was increased by using luciferase as a reporter gene; luciferase constructs give a 30 - to 1000 -fold higher signal than CAT constructs (de Wet et al., 1985, 1987; Ow et al., 1987). The transfected promoter constructs (Fig. 5; constructs 1-5) produced a luciferase activity of approximately 10 - to 30 -fold over back-
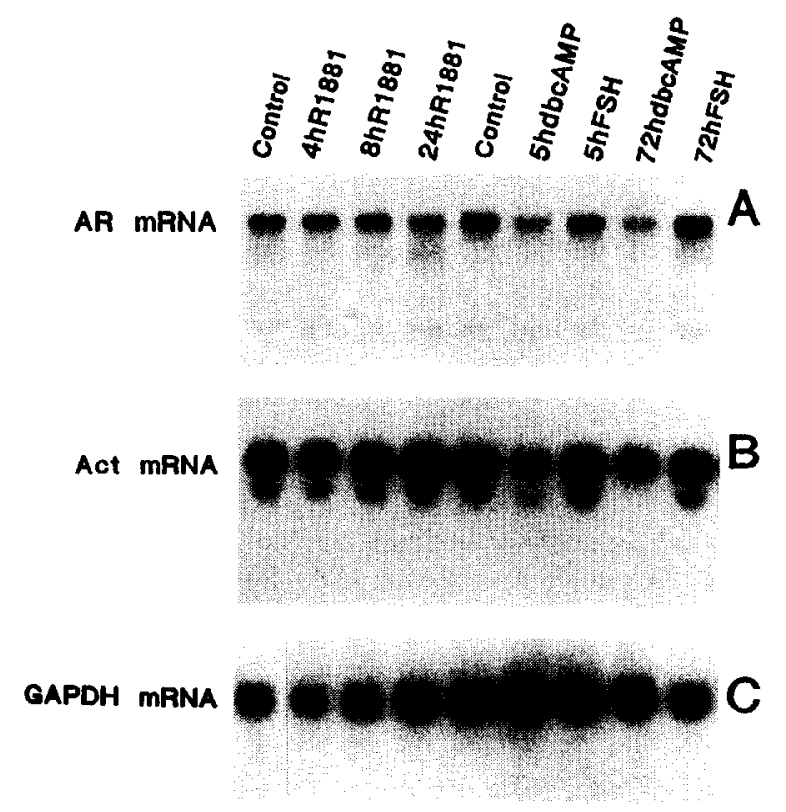

Fig. 3. Effect of FSH, dbcAMP and R1881 on AR mRNA expression in cultured peritubular myoid cells. Peritubular myoid cells from 15-day-old rats were cultured in the presence of ovine FSH-S16 $(500 \mathrm{ng} / \mathrm{ml})$, dbcAMP $(0.5 \mathrm{mM})$ or R1881 $\left(10^{-8} \mathrm{M}\right)$ for different time periods, as described in the legend to Fig. 2. For Northern analysis, $20 \mu \mathrm{g}$ of total RNA was applied per lane and analyzed using a human AR cDNA probe $(A)$; a hamster actin cDNA probe $(B)$ and a rat GAPDH cDNA probe $(C)$ were used to verify whether equal amounts of mRNA were applied to each lane on the gel. 

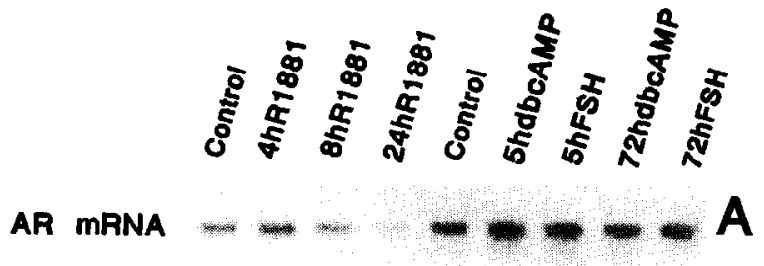

Act mRNA

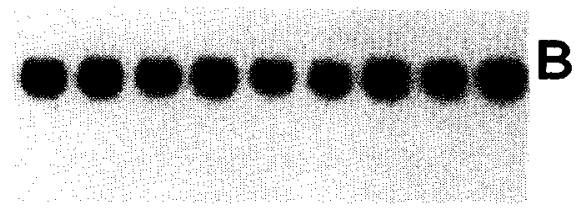

Fig. 4. Effect of FSH, dbcAMP and R1881 on AR mRNA expression in cultured $\mathrm{LNCaP}$ cells. $\mathrm{LNCaP}$ cells from pas. sages $45-50$ were cultured in the presence of ovine FSH-S16 $(500 \mathrm{ng} / \mathrm{ml})$, dbcAMP $(0.5 \mathrm{mM})$ or R1881 $\left(10^{-8} \mathrm{M}\right)$ for different time periods, as described in the legend to Fig. 2. For Northern analysis, $20 \mu \mathrm{g}$ of total RNA was applied per lane and analyzed using a human AR cDNA probe $(A)$; a hamster actin cDNA probe $(B)$ was used to verify whether equal amounts of mRNA were applied to each lane on the gel. ground. Hormone-induced changes in luciferase activity were interpreted as changes in AR promoter activity (de Wet et al., 1987). In some experiments $\beta$-galactosidase was used as an internal control for transfection efficiency. Different plasmid preparations showed approximately 2fold variation in transfection efficiency; however, no differences were observed in $\beta$-galactosidase transcription efficiency between the dbcAMP, R1881 or control incubated cells.

Because the Sertoli cell clusters were isolated in the presence of trypsin and used within $4 \mathrm{~h}$ after isolation, there was the possibility that FSH receptors were damaged by the protease. Therefore, stimulation of transcription of the transfected promoter constructs was performed using dbcAMP rather than FSH. As a control, the mouse Sertoli cell line TM4 (Mather, 1980) was transfected and incubated with FSH.

\section{AR gene transcription}

Several constructs (Fig. 1) were used to study AR gene transcription in Sertoli and LNCaP

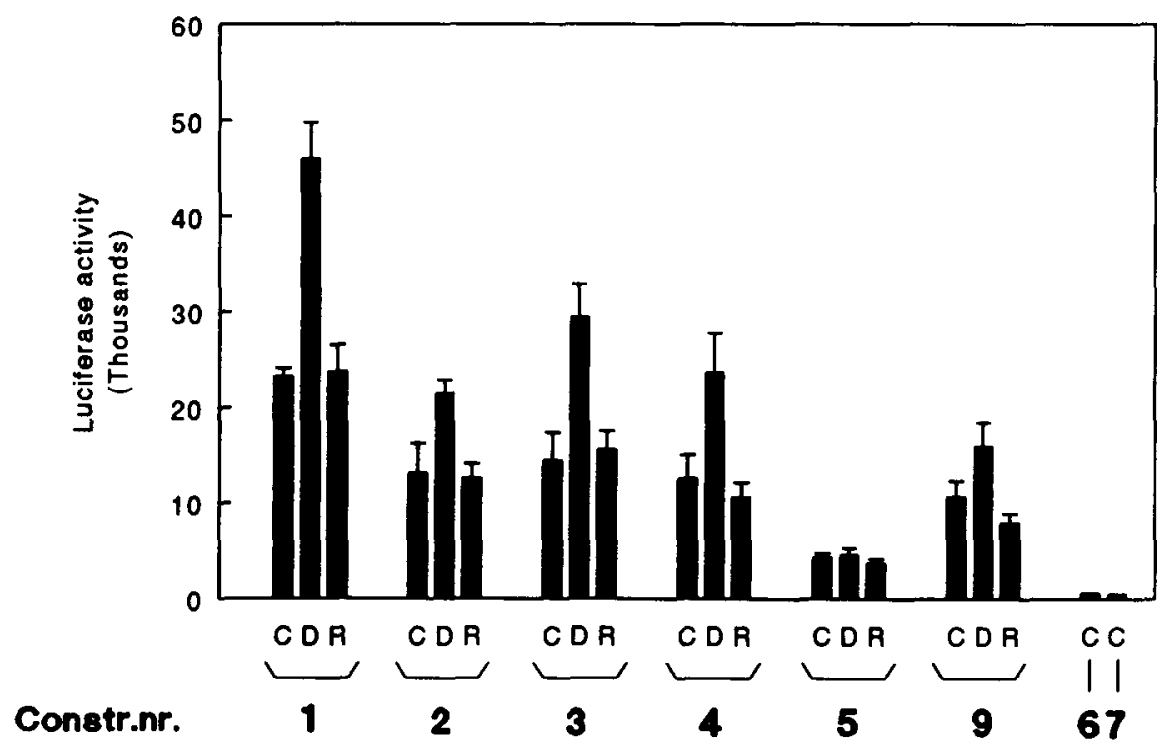

Fig. 5. Luciferase activity in whole cell lysates from transfected Sertoli cells. The Sertoli cells were transfected with different constructs (construct numbers are presented below the figure), and cultured in the presence of $\mathrm{dbcAMP}(0.5 \mathrm{mM})$ or R1881 (10 ${ }^{-8}$ $\mathrm{M}) . \mathrm{C}=$ control; $\mathrm{D}=$ cultured for $24 \mathrm{~h}$ in the presence of dbcAMP; $\mathrm{R}=$ cultured for $24 \mathrm{~h}$ in the presence of $\mathrm{R} 1881$. The activity of constructs 6 and 7 was very low. The luciferase activity was measured in four different transfections in one representative experiment. The bars represent the mean \pm SD. 
cells. In transfected Sertoli cells, transcription of the luciferase reporter gene from constructs containing AR promoter sequences was increased approximately $50-100 \%$ by incubation of the cells in the presence of dbcAMP (Fig. 5; constructs $1-4)$. This increase was not found using construct 5 , that contained only $5^{\prime}$ untranslated cDNA sequences. A positive control, containing cAMP response elements (CREs), also showed a 1.5- to 2-fold stimulated transcription. In primary Sertoli cell cultures, AR promoter activity was not stimulated by FSH (constructs $1-4$; not shown), most likely due to loss of FSH receptors during the cell isolation procedure. However, when these constructs were transfected into TM4 cells, their transcription was stimulated approximately 1.5 fold by FSH (not shown).

The 1.5- to 2-fold stimulation of construct transcription by dbcAMP/FSH in the transfected Sertoli cells and TM4 cells indicates that FSH may stimulate the transcription of the AR gene in Sertoli cells, through the cAMP pathway.

Addition of R1881 to the Sertoli cell cultures had no effect on the transcription of the transfected constructs (Fig. 5).
In nuclear run-on experiments, performed on isolated Sertoli cell nuclei, no marked increase in AR gene transcription rate was observed when the nuclei were isolated after 24 or $72 \mathrm{~h}$ of culture of the cells in the presence of FSH (Fig. $7 A)$.

\section{Transfection of LnCaP cells}

In non-transfected LNCaP cells, cultured in the presence of R1881 for 8 or $24 \mathrm{~h}$, a marked inhibition of AR mRNA expression was observed (Fig. 4A). However, LNCaP cells transfected with AR gene constructs (Fig. 1; constructs 1-5) and cultured in the presence of R1881, did not show an inhibition of luciferase transcription (Fig. 6; only the pSLA3-H2/3 construct is shown, but all other constructs were also negative). A positive control construct containing a glucocorticoid response element showed a dose-dependent increase in transcription, up to 20 -fold induction (Fig. 6). From these results it cannot be concluded that androgen-induced down-regulation of AR mRNA expression in LNCaP cells results from decreased AR gene transcription. Measurement of transfection efficiency in the different

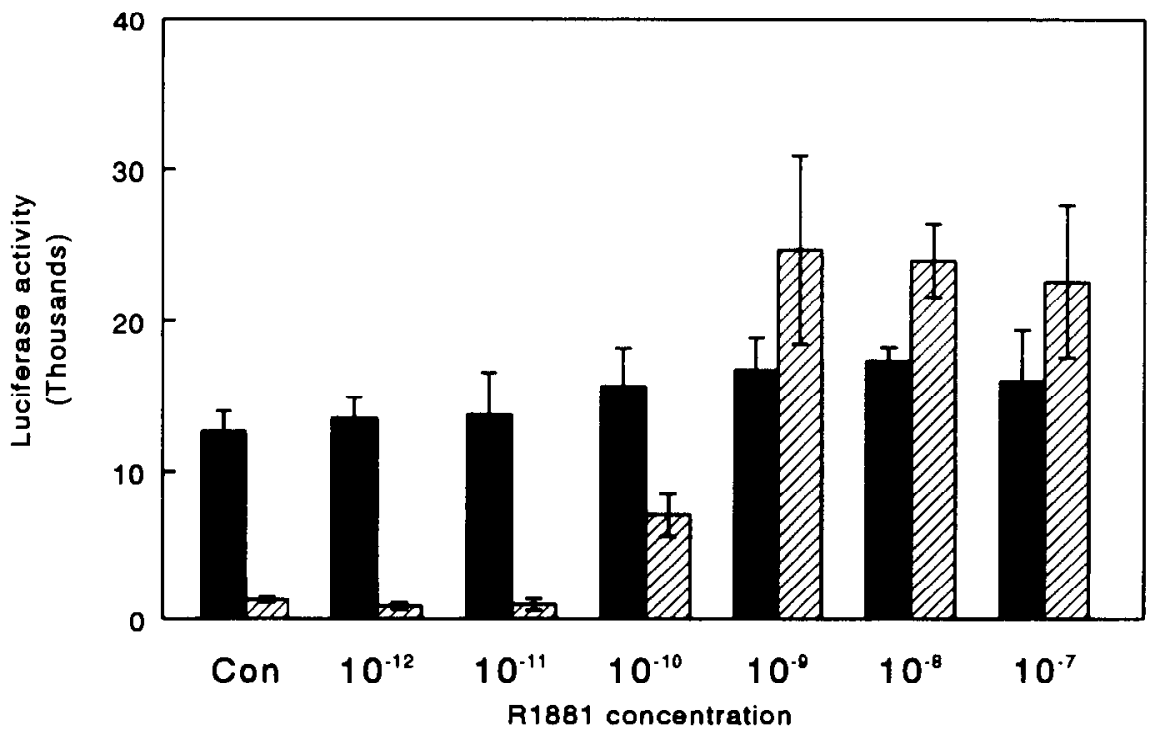

Fig. 6. Luciferase activity in whole cell lysates from transfected LNCaP cells. LNCaP cells were transfected with pSLA3-GRE-oct (a positive control; shaded bars), and with pSLA3-H2/3-E3k (construct 2, an AR promoter containing construct; closed bars). After transfection, the cells were incubated for $24 \mathrm{~h}$ in the presence of different concentrations of $\mathrm{R} 1881\left(10^{-12}\right.$ to $\left.10^{-7} \mathrm{M}\right)$. The lucifcrase activity was measured in four different transfections in one representative experiment. The bars represent the mean $\pm S D$. 

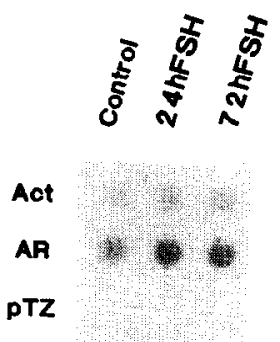

A

\section{A}

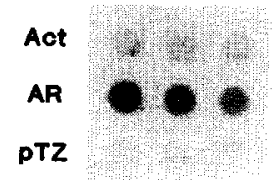

B

Fig. 7. Measurement of the initiation rate of AR gene transcription in cultured Sertoli cells $(A)$ and LNCaP cells $(B)$. Sertoli cells were cultured in the presence of ovine FSH-S16 ( $500 \mathrm{ng} / \mathrm{ml}$ ), for 24 or $72 \mathrm{~h}$. LNCaP cells were cultured in the presence of R1881 $\left(10^{-8} \mathrm{M}\right)$, for 8 or $24 \mathrm{~h}$. Nuclei were isolated and transcriptional run-on experiments were performed as described in Materials and methods. 24hFSH, $72 \mathrm{hFSH}=$ cultured for $24 \mathrm{~h}$ or $72 \mathrm{~h}$ in the presence of FSH; $8 \mathrm{hR} 1881,24 \mathrm{hR} 1881=$ cultured for $8 \mathrm{~h}$ or $24 \mathrm{~h}$ in the presence of $\mathrm{R} 1881 ; \mathrm{AR}=$ androgen receptor; Act $=$ actin; $\mathrm{pTZ}=$ control plasmid. The experiment was repeated 2 times with the same results. The autoradiograph shows the results from one experiment.

treatment groups revealed no significant differences.

To study whether or not transcription of the native androgen receptor gene, possibly containing one or several negative androgen response elements (nARE) far upstream or in one of the introns, can be regulated by androgens, a nuclear run-on experiment was performed. The results from the run-on assay indicated that AR gene transcription in $\mathrm{LNCaP}$ cells is subject to moderate down-regulation by androgens (Fig. $7 B$ ). Inhibition of $A R$ gene transc ription rate in $\mathrm{LNCaP}$ cells was quantitated using densitometric scanning. The measured values were $0.86 / 0.84$ after 8 $\mathrm{h}$ and $0.70 / 0.76$ after $24 \mathrm{~h}$ of culture in the presence of R1881.

\section{Discussion}

Differential regulation of $A R M R N A$ expression by $F S H, d b c A M P$ and androgens

Regulation of AR mRNA expression by FSH is a cell-specific event, because Sertoli cells are the only cells in the male body that express detectable amounts of the FSH receptors (Dorrington et al., 1975). We have shown (Blok et al., 1992b) that addition of FSH to cultured imma- ture Sertoli cells resulted in a short-term transient decrease $(5 \mathrm{~h})$ in AR mRNA expression, that was followed by a long-term increase (24-72 h). Dibutyryl-cyclic AMP (dbcAMP) mimicked the FSH effect, indicating that also for this effect cAMP is used as an important second messenger to transduce the FSH signal from the Sertoli cell surface to the interior of the cell. Obviously, the cAMP signal transduction pathway, activated by $\mathrm{G}$ protein-coupled receptors, is not Sertoli cell specific. Therefore, we have tested whether the addition of dbcAMP to other AR containing cells might exert a similar effect on AR mRNA expression.

In peritubular myoid cells from the testis, a small decrease in AR mRNA expression was observed when the cells were cultured in the presence of dbcAMP ( $5 \mathrm{~h}$ and $72 \mathrm{~h}$ ). In LNCaP cells there was no effect of dbcAMP at all. This contrasts with the marked regulatory effects of dbcAMP (or FSH through cAMP) on Sertoli cells.

With respect to androgen action, AR mRNA expression in LNCaP cells was reduced atter the addition of androgens to the culture medium. Other authors have observed a similar down-regulatory androgen effect in LNCaP cells (Quarmby et al., 1990; Tilley et al., 1990; Trapman et al., 1990; Krongrad et al., 1991). Furthermore, androgen administration to castrated rats down-regulated AR mRNA expression in ventral prostate (Lubahn et al., 1988; Tan et al., 1988; Quarmby et al., 1990; Blok et al., 1992a), kidney, brain, coagulating gland (Quarmby et al., 1990) and epididymis (Quarmby et al., 1990; Blok et al., 1992a). Such a down-regulatory androgen effect, however, was not found in cultured Sertoli and peritubular myoid cells (Blok et al., 1989; Sanborn et al., 1991). Furthermore, androgen withdrawal from the adult rat testis, by use of the toxic compound ethane dimethane sulphonate that eliminates Leydig cells, also did not result in altered testicular AR mRNA expression (Blok et al., 1991, 1992a).

The present data underline that regulation of AR mRNA expression in rat testis by $\mathrm{FSH}$, dbcAMP and androgens is different, when compared with AR mRNA expression regulation in LNCaP cells or several other rat tissues and organs. 


\section{AR gene transcription}

For the short-term $(5 \mathrm{~h})$ down-regulation of AR mRNA expression in Sertoli cells by FSH, it has been shown that the rate of initiation of AR gene transcription was not markedly changed (Blok et al., 1992b). The FSH/dbcAMP-induced decline in AR mRNA expression seems to be the result of a marked decrease in AR mRNA stability (Blok et al., 1992b).

For the long-term (24-72 h) FSH-induced stimulation of AR mRNA expression in Sertoli cells, and for the androgen-induced decrease in AR mRNA expression in LNCaP cells, AR gene transcription was studied in the present experiments.

Two different approaches were chosen to examine AR gene transcription. First, several different AR gene promoter regions were inserted in front of a reporter gene. These constructs were transfected into Sertoli and LNCaP cells, which were then incubated in the presence or absence of hormones. After $24 \mathrm{~h}$, reporter activity was measured. Second, using a nuclear transcription elongation assay (run-on), the transcription initiation rate was mcasured in FSH-stimulated Scrtoli cells $(0,24$ and $72 \mathrm{~h})$, and in androgen-treated LNCaP cells $(0,8,24 \mathrm{~h})$.

Stimulation of $A R$ gene transcription by FSH or dbcAMP in Sertoli cells

Using different constructs that contained the AR gene promoter region, a stimulation of construct transcription by dbcAMP was observed in transfected Sertoli cells, that was not observed for the construct that contained only the $5^{\prime}$ untranslated region of the cDNA sequence. The transcription of a positive control, a CRE-containing construct, was stimulated $50 \%$, which is low when compared to a 5- to 7-fold stimulation of the transcription of this CRE construct when transfected into other cell types (Dean et al., 1989). In LNCaP cells we observed a 5-fold increase in transcription of the CRE construct (not shown).

The results indicate that there is a small but reproducible increase, induced by dbcAMP, in the transcription of the AR promoter containing constructs transfected into Sertoli cells. Furthermore, the present results suggest that sequences in the promoter region of the AR gene play a role in the stimulatory effect of FSH (dbcAMP) on the transcription of this gene in Sertoli cells. Analysis of the sequence of the AR promoter region (Baarends et al., 1990), however, revealed no known CRE consensus sequences that could be responsible for the observed effects.

In the current investigations, the transcription of AR promoter containing constructs was elevated by only $50-100 \%$ upon dbcAMP addition to the Sertoli cell cultures. These differences were judged too small to warrant identification of the sequences that are involved in cAMP-induced regulation of AR gene transcription in Sertoli cells by means of mutation analysis.

\section{Inhibition of $A R$ gene transcription by androgens in} LNCaP cells

The general concept of androgen action involves that androgens bind to the AR, that subsequently becomes transformed to its DNA binding form and then regulates transcription of androgen responsive genes (Schrader et al., 1981; Beato, 1990; Wahli and Martinez, 1991). LNCaP cells contain large amounts of AR protein, and these ARs become transformed to the tight nuclear binding form in the presence of R1881 (Veldscholte et al., 1990). Furthermore, a clear downregulatory effect of R1881 addition on AR mRNA expression (8-24 h) was found (Krongrad et al., 1991). In the present experiments it was investigated whether these observations can be explained by a reduced level of AR gene transcription.

To this end, the AR gene promoter constructs were transfected into $\mathrm{LNCaP}$ cells, and assayed for their response to androgen treatment. The positive control, a construct containing a glucocorticoid responsive element which can also be regulated by the androgen receptor (GRE; Schüle et al., 1988) cloned in front of the Oct-6 minimal promoter, showed a marked stimulation of transcription after androgen addition to the LNCaP cells. The transcription of the AR promoter constructs, however, appeared not to be regulated by androgens. Although the constructs contained large portions of the $5^{\prime}$ upstream region of the AR gene promoter, these experiments do not exclude the possibility that androgen response 
elements are located in other parts of the gene. For example for the $\mathrm{C} 3$ gene, encoding a component of prostatic binding protein, an androgen response element has been described in the first intron of the gene (Claessens et al., 1990; Tan et al., 1992). The putative nARE, however, can also be located further upstream, in an area of the AR gene that has not been investigated sofar. Nuclear run-on experiments were performed to investigate whether or not the native gene is subject to transcriptional regulation.

Measurement of the transcription initiation rate of the AR gene in $\mathrm{LNCaP}$ cells indicated that androgen treatment resulted in a $30 \%$ reduction of transcription. Therefore, androgen-induced inhibition of AR mRNA expression in LNCaP cells may result in part or completely from decreased AR gene transcription.

In conclusion, regulation of the expression of the AR gene in Sertoli, peritubular myoid and LNCaP cells differs markedly. In Sertoli cells, FSH/dbcAMP can stimulate AR gene transcription, whereas androgens have no effect. In LNCaP cells, dbcAMP has no effect on AR mRNA expression, while androgens inhibit AR gene transcription. In peritubular myoid cells neither dbcAMP nor androgens were found to have a marked effect on AR mRNA regulation. Therefore, it appears that the mode of control of AR gene transcription is cell type dependent.

\section{Acknowledgements}

This work was supported financially by the Dutch Science Foundation (NWO) through GBMW (Medical Sciences). A.T. is recipient of a fellowship of the Royal Academy of Sciences (KNAW Fellow Program). Ovine FSH-S16 was provided by NIH (Bethesda, MD, USA). The authors wish to thank Drs. D. Meijer and G. Grosveld for providing the octamer 6 binding protein promoter and Dr. R. Offringa for providing the human fibronectin CRE sequence.

\section{References}

Baarends, W.M., Themmen, A.P.N., Blok, L.J., Mackenbach, P., Brinkmann, A.O., Meijer, D., Faber, P.W., Trapman, J. and Grootegoed, J.A. (1990) Mol. Cell. Endocrinol. 74, 75-84.

Bartlett, J.M.S., Weinbauer, G.F. and Nieschlag, E. (1989) J. Endocrinol. 1, 49-58.

Beato, M. (1990) Cell 56, 335-344.

Blok, L.J., Mackenbach, P., Trapman, J., Themmen, A.P.N., Brinkmann, A.O. and Grootegoed, J.A. (1989) Mol. Cell. Endocrinol. 63, 267-271.

Blok, L.J., Bartlett, J.M.S., Bolt-de Vries, J., Themmen, A.P.N., Brinkmann, A.O., Weinbauer, G.F., Nieschlag, E. and Grootegoed, J.A. (1992a) Int. J. Androl. (in press).

Blok, L.J., Hoogerbrugge, J.W., Themmen, A.P.N., Baarends, W.M., Post, M. and Grootegoed, J.A. (1992b) Endocrinology (in press).

Chen, C. and Okayama, H. (1987) Mol. Cell. Biol. 7, 27452752.

Cheng, C.Y., Mather, J.P., Byer, A.L. and Bardin, C.W. (1986) Endocrinology 118, 480-488.

Claessens, F., Rushmere, N.K., Davies, P., Celis, L., Peeters, B. and Rombauts, W.A. (1990) Mol. Cell. Endocrinol. 74, 203-212.

Clermont, Y. and Harvey, S.C. (1967) in Ciba Foundation Colloquia on Endocrinology, Vol. 16, pp. 173-189, Churchill, London.

Dean, D.C., Blakeley, M.S., Newby, R.F., Ghazal, P., Hennighausen, L. and Bourgeoid, S. (1989) Mol. Cell. Biol. 9, 1498-1506.

de Wet, J.R., Wood, K.V., Helsinki, D.R. and DeLuca, M. (1985) Proc. Natl. Acad. Sci. USA 82, 7870-7873.

de Wet, J.R., Wood, K.V., DeLuca, M., Helsinki, D.R. and Subramani, S. (1987) Mol. Cell. Biol. 7, 725-737.

Dorrington, J.H., Roller, N.F. and Fritz, I.B. (1975) Mol. Cell. Endocrinol. 3, 57-70.

Faber, P.W.F., van Rooij, H.C.J., van der Korput, J.A.G.M., Baarends, W.M., Brinkmann, A.O., Grootegoed, J.A. and Trapman, J. (1991) J. Biol. Chem. 266, 10743-10749.

Fritz, I.B. (1978) in Biochemical Actions of Hormones (Litwack, G., ed.), Vol. 5, pp. 249-281, Academic Press, New York.

Hansson, V., Weddington, S.C., McLean, W.S., Smith, A.A., Nayfeh, S.N., French, F.S. and Ritzen, E.M. (1975) J. Reprod. Fertil. 44, 363-375.

Horoszewicz, J.S., Leong, S.S., Kawinski, E., Karr, J.P., Rosenthal, H., Chu, T.M., Mirand, E.A. and Murphy, G.P. (1983) Cancer Res. 43, 1809-1818.

Jenster, G., van der Korput, J.A.G.M., van Vroonhoven, C., van der Kwast, T.H., Trapman, J. and Brinkmann, A.O. (1991) Mol. Endocrinol. 5, 1396-1404.

Krongrad, A., Wilson, C.M., Wilson, J.D., Allman, D.R. and McPhaul, M.J. (1991) Mol. Cell. Endocrinol. 76, 79-88.

Lubahn, D.B., Sar, M., Tan, J., Higgs, H.N., Larson, R.E., French, F.S. and Wilson, E.M. (1988) Mol. Endocrinol. 2, $1265-1275$

Marshall, G.R. and Nieschlag, E. (1987) in Inhibins: Isolation, Estimation and Physiology (Sheth, A.R., ed.), Vol. 1, pp. 3-15, CRC Press, Boca Raton, FL.

Mather, J.P. (1980) Biol. Reprod. 23, 243-252. 
Matsumoto, A.M. and Bremner, W.J. (1989) J. Steroid Biochem. 33, 789-790.

Ow, D.W., Wood, K.V., DeLuca, M., De Wet, J.R., Helinski, D.R. and Howell, H. (1986) Science 234, 856-859.

Palombi, F. and Di Carlo, C. (1988) Biol. Reprod. 39, 11011109.

Quarmby, V.E., Yarbrough, W.G., Lubahn, D.B., French, F.S. and Wilson, E.M. (1990) Mol. Endocrinol. 4, 22-28.

Russell, L.D., Alger, L.E. and Nequin, L.G. (1987) Endocrinology 120, 1615-1632.

Sambrook, J., Fritsch, E.F. and Maniatis, T. (1989) Molecular Cloning, A Laboratory Manual (Nolan, C., ed.), 2nd edn., Cold Spring Harbor Laboratory Press, Cold Spring Harbor, NY.

Sanborn, B.M., Caston, L.A., Chang, C., Liao, S., Speller, R., Porter, L.D. and Ku, C.Y. (1991) Biol. Reprod. 45, 634641.

Schrader, W.T., Birnbaumer, M.E., Hughes, M.R., Weigel, N.L., Grody, W.W. and O'Malley, B.W. (1981) in Recent Progress in Hormone Research (Greep, R.O., ed.), Vol. 37, pp. 583-633, Academic Press, New York.

Schüle, R., Muller, M., Kaltschmidt, C. and Renkawitz, R. (1988) Science 242, 1418-1420.

Steinberger, E. (1971) Physiol. Rev. 51, 1-22.

Tan, J., Joseph, D.R., Quarmby, V.E., Lubahn, D.B., Sar, M. and French, F.S. (1988) Mol. Endocrinol. 12, 1265-1275.

Tan, J., Marschke, K.B., Ho, K., Perry, S.T., Wilson, E.M. and French, F.S. (1992) J. Biol. Chem. 267, 4456-4466.
Themmen, A.P.N., Blok, L.J., Post, M., Baarends, W.M., Hoogerbrugge, J.W., Parmentier, M., Vassart, G. and Grootegoed, J.A. (1991) Mol. Cell. Endocrinol. 78, R7R13.

Tilley, W.D., Wilson, C.M., Marcelli, M. and McPhaul, M.L. (1990) Cancer Res. 50, 5382-5386.

Trapman, J., Klaassen, P., Kuiper, G.G.J.M., van der Korput, J.A.G.M., Faber, P.W.F., van Rooij, H.C.J., Geurts van Kessel, A., Voorhorst, M.M., Mulder, E. and Brinkmann, A.O. (1988) Biochem. Biophys. Res. Commun. 153, 241248.

Trapman, J., Ris-Stalpers, C., van der Korput, J.A.G.M., Kuiper, G.G.J.M., Faber, P.W., Romijn, J.C., Mulder, E. and Brinkmann, A.O. (1990) J. Steroid Biochem. Mol. Biol. 6, 837-842.

van Dijk, M.A., van Schaik, F.M.A., Bootsma, H.J., Holthuizen, P. and Sussenbach, J.S. (1991) Mol. Cell. Endocrinol. 81, 81-94.

Veldscholte, J., Ris-Stalpers, C., Kuiper, G.G.J.M., Jenster, G., Berrevoets, C., Claassen, E., Rooij, H.C.J., Trapman, J., Brinkmann, A.O. and Mulder, E. (1990) Biochem. Biophys. Res. Commun. 173, 534-540.

Verhoeven, G. and Cailleau, J. (1988) Endocrinology 122, 1541-1550.

Wahli, W. and Martinez, E. (1991) FASEB J. 5, 2243-2249. 